\title{
Desain dan Analisa Ekonomi PLTS Atap untuk Villa di Bali
}

\author{
I Kadek Sumariana ${ }^{1}$, I Nyoman Satya Kumara ${ }^{2}$, Wayan Gede Ariastina ${ }^{3}$ \\ Submission: 15-08-2019, Accepted: 27-08-2019
}

\begin{abstract}
Bali province is one of $\mathbf{3 4}$ provinces of Indonesia and according to General Plan of National Energy it is expected to develop around $110 \mathrm{MW}$ solar PV by 2025 . Economically, Bali is considered as the center of Indonesian tourism industry. A wide range of accommodations have been developed to support the industry including villa. In this paper, potential of rooftop PV of villas in Bali is presented. Rooftop PV capacity is designed with objective to meet $23 \%$ of the villa's energy consumption. Two villas in the southern of Bali were taken as examples. Energy audit is conducted to study the energy usage of both villas. Based on the design objective, $13,7 \mathrm{kWp}$ grid-connected $\mathrm{PV}$ is proposed for each of the villa. With these results, it is projected that all villas in Bali could add solar PV capacity around 34,8 MWp which canpotentialy generateannual energy of $54.750 \mathrm{MWh}$. Investment analysis are also included on this paper. The results presented here will help provincial and district governments of Bali to get insight into potential of tourism sector to support PV development and subsequentlyto developappropriate policies and regulations to accelerate the uptake of rooftop $\mathrm{PV}$ in Bali.
\end{abstract}

Intisari-Provinsi Bali adalah salah satu dari 34 provinsi di Indonesia dan menurut Rencana Umum Energi Nasional diharapkan untuk mengembangkan sekitar 110 MW solar PV pada tahun 2025. Secara ekonomi, Bali dianggap sebagai pusat industri pariwisata Indonesia. Berbagai akomodasi telah dikembangkan untuk mendukung industri termasuk villa. Dalam tulisan ini, potensi Rooftop PV pada villa di Bali disajikan. Kapasitas Rooftop PV dirancang dengan tujuan untuk memenuhi $23 \%$ dari konsumsi energi villa. Dua villa diBali selatan diambil sebagai contoh. Audit energi dilakukan untuk mempelajari penggunaan energi kedua villa. Berdasarkan tujuan desain, 13,7 kWp PV yang terhubung ke jaringan diusulkan untuk masing-masing villa. Dengan hasil ini, diproyeksikan bahwa semua villa di Bali dapat menambah kapasitas solar PV sekitar 34,8 MWp yang berpotensi menghasilkan energi tahunan 54.750 MWh. Analisis investasi juga dimasukkan dalam makalah ini. Hasil yang disajikan di sini akan membantu pemerintah provinsi dan kabupaten di Bali untuk mendapatkan wawasan tentang potensi sektor pariwisata untuk mendukung pengembangan $P V$ dan selanjutnya mengembangkan kebijakan dan peraturan yang sesuai untuk mempercepat penyerapan Rooftop PV di Bali.

Kata Kunci-Energi terbarukan, Rooftop PV,Grid-connected, Pengurangan emisi, Pariwisata hijau.

\footnotetext{
${ }^{1}$ Mahasiswa, Program Studi Magister Teknik Elektro Universitas Udayana, Lingk. Sawangan, Badung 80361 INDONESIA (tlp: $08179796277 ; \quad$ fax:-; e-mail: kadeksumariana08@gmail.com)

${ }^{2,3}$ Dosen, Program Studi Magister Teknik Elektro Universitas Udayana, Jln. PB. Sudirman, Denpasar 80232 INDONESIA (telp: 0361-239599;fax:-; e-mail: $\quad{ }^{2}$ ins_kumara@yahoo.com, w_ariastina@yahoo.com)
}

I Kadek Sumariana : Penilaian Potensi Akomodasi Tipe...

\section{PENDAHULUAN}

Kebijakan energi Indonesia tertuang dalam Peraturan Pemerintah Nomor 79 Tahun 2014 tentang Kebijakan Energi Nasional (KEN). Di dalam KEN disebutkan bahwa target Energi Baru Terbarukan (EBT) adalah sebesar 23\% dalam bauran energi pada tahun 2025. Indonesia merupakan Negara kepulauan yang terdiri dari 34 provinsi dengan potensi energi terbarukan yang melimpah seperti tenaga air, panas bumi, biomassa, angin dan surya yang bersih, sehingga ramah lingkungan dan tersedia secara berkelanjutan. Salah satu sumber energi terbarukan yang dapat dikembangkan di Indonesia adalah matahari. Karena posisi Indonesia dekat dengan khatulistiwa, rata-rata radiasi matahari adalah 4,8 $\mathrm{kWh} / \mathrm{m}^{2} /$ hari. Pada periode antara 2010 dan 2011 , pemerintah Indonesia telah membangun lebih dari 100 sistem photovoltaic (PV) dengan total kapasitas 80 MWp dari 100 lokasi diberbagai pulau di Indonesia. Tahun 2025, Pemerintah Indonesia menetapkan target kapasitas nasional PV sebesar 6.500 MWp [1]. Sayangnya, sampai saat ini total kapasitas PLTS nasional masih jauh dari target yang telah ditetapkan sehingga ke depan perlu dilakukan berbagai terobosan agar target PLTS 2025 bisa dicapai.

Pulau Bali merupakan salah satu provinsi di Indonesia yang mempunyai radiasi harian matahari rata-rata $5,3 \mathrm{kWh} / \mathrm{m}^{2}$ dengan solar radiasi $1.000 \mathrm{Watt} / \mathrm{m}^{2}$ [2]. Salah satu proyek percontohan yang telah dikembangkan di Bali adalah Pembangkit Listrik Tenaga Surya (PLTS) 1 MWp terinterkoneksi jaringan di Kayubihi Bangli atau disebut PLTS Kayubihi dan PLTS 1 MWp Karangasem. Pengoperasian kedua PLTS berskala besar tersebut merupakan suatu hal baru di Indonesia [3]. Di samping itu, berbagai proyek PLTS telah dikembangkan di Bali, namun akumulasi kapasitas terpasang juga masih rendah [4].

Di pulau Bali, pasokan daya listrik masih didominasi oleh pembangkitan berbahan bakar fosil dengan total daya mampu PLN Bali mencapai 1.300 MW dengan beban puncak 830 MW pada tahun 2016. Pembangkitan energi listrik di Bali berasal dari PLTG Gilimanuk 130 MW, Pembangkit Pemaron 80 MW, PLTU Celukan Bawang 380 MW dan Kabel Laut Jawa Bali 340 MW.PT PLN Distribusi Bali memperkirakan pertumbuhan listrik Bali pertahun berada di kisaran 12\% [5].

Salah satu faktor penyebab meningkatnya permintaan energi listrik di Bali adalah perkembangan sektor pariwisata. Bali merupakan pusat pariwisata Indonesia. Dari tahun 2013 sampai 2017 peningkatan kunjungan wisatawan adalah sebesar 14,6\%. Peningkatan kunjungan wisatawan harus diikuti dengan pembangunan fasilitas kepariwisataan termasuk akomodasi pariwisata seperti hotel dan villa. Pada tahun 2013, jumlah akomodasi pariwisata sebanyak 2.572-unit dan pada tahun 2017 meningkat menjadi 4.290-unit yang terdiri dari 1.748-unit hotel bintang maupun non bintang dan 2.542-unit villa [6]. Dari sisi jumlah pemakaian energi listrik, p-ISSN:1693 - 2951; e-ISSN: 2503-2372 
komposisi dari tiap jenis pelanggan antara lain pelanggan bisnis sebesar 48,8\%, rumah tangga 40,6\%, publik 3,5\%, industri $3,4 \%$, sosial $2,6 \%$ dan layanan khusus sebesar $1,0 \%$ [7].

Peranan sektor pariwisata di Bali seperti villa untuk ikut berpartisipasi dalam pengembangan PLTS sangat potensial. Villa dengan konsep green energy akan memiliki nilai jual lebih baik karena disamping memberikan kenyamanan serta bebas polusi juga ikut mengurangi emisi gas buang, sehingga tamu yang sudah sadar dengan perlindungan lingkungan berpotensi akan memilih tinggal di akomodasi yang telah mengadopsi energi hijau. Disamping itu, pengembangan green energy di sektor pariwisata sejalan dengan program pemerintah daerah yaitu Bali Green Province yang dalam implementasinya memerlukan partisipasi seluruh komponen masyarakat dan pelaku usaha [8][9]. Partisipasi sektor pariwisata seperti villa dalam pengembangan energi terbarukan diharapkan dapat mengurangi ketergantungan akan sumber energi listrik yang masih bergantung pada bahan bakar fosil.

Identifikasi atau kajian terhadap potensi sektor pariwisata dalam mendukung perkembangan pariwisata telah menjadi perhatian peneliti-peneliti di pusat-pusat pariwisata dunia. Seperti, proyek HOTRES di lima wilayah UE (East Attica, Sicily, Alpes-Maritimes, Andalusia and Madeira) yang mempromosikan lima teknologi energi terbarukan (solar thermal, solar passive, solar PV, biomass and geothermal energy) dengan tujuan implementasi sistematis kondisi untuk aplikasi masif masa depan dari energi terbarukan di industri pariwisata [10]. Pemanfaatan energi surya dalam pengembangan pariwisata berkelanjutan di pulau-pulau Mediterania, dengan tujuan pengembangan ekonomi pariwisata melalui bentuk pariwisata tematik dan produk serta layanan pariwisata yang berbeda [11]. Penerapan teknologi energi terbarukandalam pengembangan pariwisata pedesaan rendah karbon di Changsha, China [12]. Potensi pemanfaatan rooftop PV yang belum diatur di negara berkembang, studi kasus di sektor perumahan Kerajaan Arab Saudidengan mempertimbangkan dua jenis bangunan yaitu apartemen dan villa [13]. Kelayakan ekonomi sistem PV di hotel-hotel di Meksiko, dengan tujuan menentukan kondisi yang menguntungkan untuk menghasilkan energi listrik melalui sistem PV [14].

Tujuan dari makalah ini adalah untuk menilai potensi rooftop PV pada akomodasi tipe villa di Bali untuk mendukung mewujudkan target PV dan juga program Bali Green Province. Hasil yang disajikan dalam makalah ini akan membantu pemerintah pusat dan daerah, industri pariwisata, dan masyarakat umum untuk memahami potensi rooftop PV dalam mewujudkan target PV provinsi sebagai bagian dari rencana 2020 solar PV nasional.

\section{STUDI LITERATUR}

Penelitian ini akan mengkaji potensi pemanfaatan sistem rooftop PV pada dua jenis villa yang berbeda yaitu private villa dan resort villa. Private villa adalah villa yang berfungsi sebagai tempat untuk peristirahatan keluarga yang dimiliki oleh perorangan tanpa tujuan komersial, sedangkan resort villa adalah villa yang berbentuk resort yang bangunannya terpisah-pisah seperti halnya sebuah villa, yang memiliki pelayanan villa berbintang dengan segala kelebihan fasilitasnya dapat ditemukan pada villa jenis ini [15]. Untuk private villa, penelitian dilakukan di villa Uluwatu 318, Desa Pecatu Kabupaten Badung dan resort villa di villa The Shanti Residence, Nusa Dua, Kabupten Badung.

Villa Uluwatu 318 memiliki luas kurang lebih 3.400 $\mathrm{m}^{2}$ dengan bangunan terdiri dari 6kamar tidur, 1 dapur, 1 ruang belajar, 1 ruang audio, dan 1 ruang tamu seperti pada Figure 1.Kebutuhan energi listrik di villa Uluwatu 318, disuplai oleh PLN dengan kapasitas daya sebesar 131kVA.

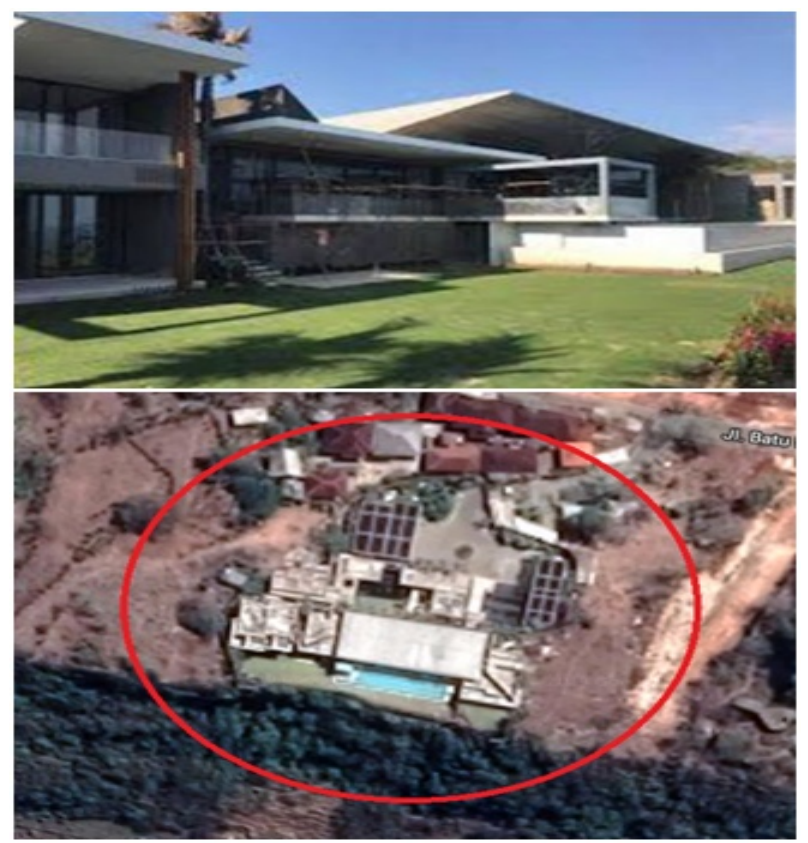

Gambar 1 : Satellite view villa Uluwatu 318

Villa The Shanti Residencemulai beroperasi pada tahun 2007, dibangun di atas tanah seluas kurang lebih $3.500 \mathrm{~m}^{2}$ dengan bangunan terdiri dari 4 kamar tidur, 1 dapur, 2 ruang belajar, 1 ruang audio, 1 ruang pijat, dan 1 ruang olahraga seperti pada Gambar 2.Kebutuhan energi listrik di Villa The Shanti Residence, disuplai oleh PLN dengan kapasitas daya sebesar 56 kVA.

Sistem solar PV yang diusulkan pada penelitian ini adalah sistem grid-connected PV. Array surya akan dipasang dengan memanfaatkan atap bangunan villa. Pemilihan sistem PV tanpa baterai bertujuan untuk meminimalkan investasi dan karena karakteristik penggunaan energi di villa yang tinggi pada siang hari. Keunggulan dari sistem rooftop PV diantaranya, lebih mudah dan murah untuk diintegrasikan dengan sistem kelistrikan yang sudah ada, dapat memanfaatkan lahan yang ada sehingga menghilangkan biaya investasi lahan baru, serta dapat turut mengurangi beban jaringan sistem yang ada [16]. 


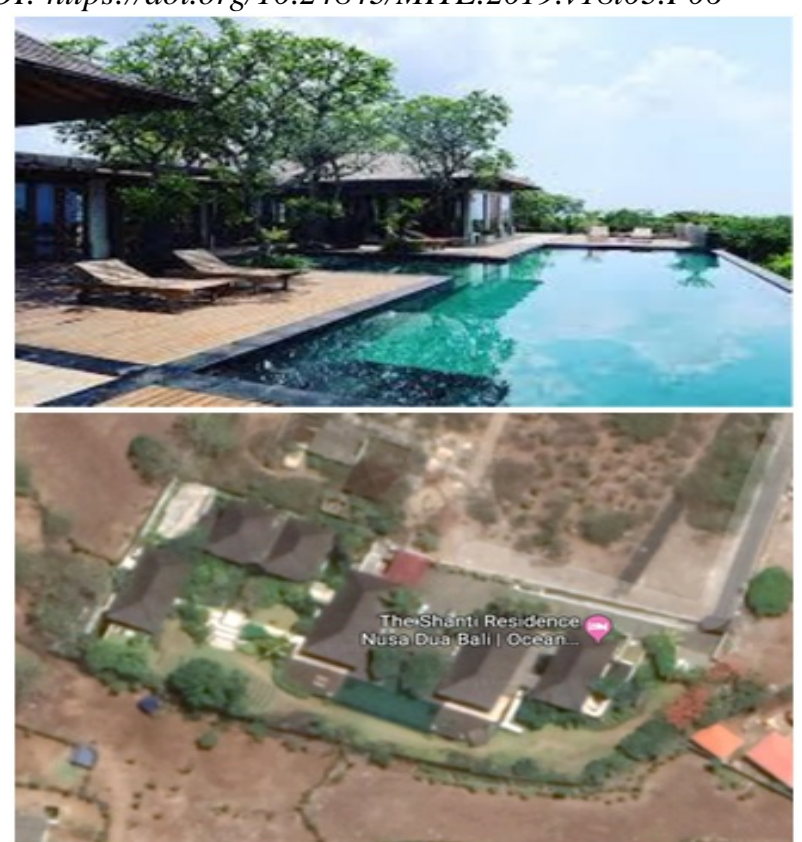

Gambar 2 : Satellite view villa The Shanti Residence

\section{METODOLOGI PENELITIAN}

Skematik metodologi penelitian yang dilakukan disajikan pada Gambar 3.

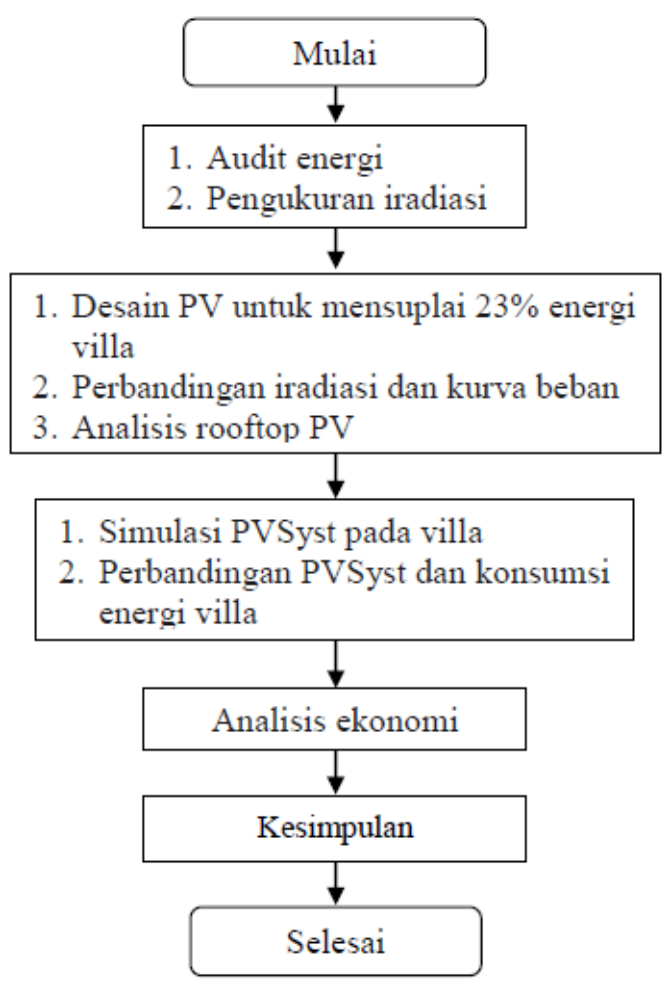

Gambar 3 : Skematik metodologi penelitian

Sesuai dengan skematik metodologi penelitian yang ditunjukkan Gambar 3, maka kegiatan pertama yang I Kadek Sumariana : Penilaian Potensi Akomodasi Tipe... dilakukan adalah melakukan audit energi sesuai dengan pedoman teknis audit energi [17], dan pengukuran iradiasi matahari pada kedua villa. Tujuan audit energi adalah untuk mengetahui konsumsi energi pada masing-masing villa sehingga dapat dipakai acuan dalam merancang kapasitas sistem PV. Sedangkan, pengukuran iradiasi matahari dilakukan menggunakan solar power meter bertujuan untuk mengetahui potensi iradiasi matahari pada masing-masing villa.

Kapasitas sistem PV yang dirancang akan mengacu pada rencana nasional untuk mencapai $23 \%$ energi terbarukan pada bauran energi tahun 2025 [1]. Pada kedua villa yang diteliti, energi listrik merupakan satu-satunya sumber energi sehingga jika $23 \%$ energi listrik yang digunakan berasal dari PV maka secara tidak langsung villa akan mendukung pencapaian target PV nasional tersebut. Penentuan kapasitas rooftop PV dilakukan dengan persamaan berikut:

$$
E_{\text {PVcap }}=23 \% x E_{\text {tot }}
$$

Dimana, $E_{P V \text { cap }}$ adalah energi yang harus mampu dihasilkan oleh sistem PV yang akan dirancang, dinyatakan dalam satuan $\mathrm{kWh}$. $E_{\text {tot }}$ adalah rata-rata total energi yang dikonsumsi oleh villa setiap hari dalam satuan $\mathrm{kWh}$.

Menentukan kebutuhan daya sistem PV dapat dihitung menggunakan persamaan berikut [18]:

$$
P_{P V}=\frac{E_{p v}}{P V_{\text {genfact }}}
$$

Dengan,

$$
\begin{aligned}
& P V_{\text {genfact }}=\frac{S R}{S T C} \\
& E_{P V}=E_{P V \text { cap }} x R_{\text {comfact }}
\end{aligned}
$$

Dimana, $P_{P V}$ adalah kebutuhan daya sistem PV dalam satuan $\mathrm{kWp}, E_{p v}$ adalah energi yang dibutuhkan modul PV dalam satuan kWh, $P V_{\text {genfact }}$ adalah faktor generasi panel, $S R$ adalah radiasi matahari dalam satuan $\mathrm{kWh} / \mathrm{m}^{2} / \mathrm{d}, S T C$ adalah kondisi standar iradiasi panel PV sebesar 1,000 W/m ${ }^{2}$ [18], $R_{\text {comfact }}$ adalah faktor kompensasi rugi sistem.

Sedangkan, total kebutuhan modul PV dapat dihitung dengan persamaan berikut [18]:

$$
P V_{\text {req }}=\frac{P_{P V}}{P V_{\text {rateout }}}
$$

Dimana, $P V_{\text {req }}$ adalah total kebutuhan modul $\mathrm{PV}, P V_{\text {rateout }}$ adalah kapasitas output modul PV dalam satuan Wp.

Total area yang dibutuhkan untuk pemasangan modul PV dapat dihitung dengan persamaan berikut [19]:

$$
\text { p-ISSN:1693 - 2951; e-ISSN: 2503-2372 }
$$




$$
P V_{\text {area }}=P V_{\text {req }} x P V_{L} x P V_{W}
$$

Dimana, $P V_{\text {area }}$ adalah total area pemasangan modul PV dalam satuan $\mathrm{m}^{2}, P V_{L}$ adalah panjang modul dan $P V_{W}$ adalah lebar modul dalam satuan $m$.

Penentuan kapasitas dan total kebutuhan inverter dapat dihitung dengan persamaan berikut [18]:

$$
\begin{aligned}
& I n_{\text {cap }}=P_{P V} x P V_{\text {systol }} \\
& I n_{\text {req }}=\frac{I n_{\text {cap }}}{I n_{\text {rateout }}}
\end{aligned}
$$

Dimana, $I n_{\text {cap }}$ adalah kapasitas inverter dalam satuan $\mathrm{kW}$, $P V_{\text {systol }}$ adalah toleransi sistem, $I n_{\text {req }}$ adalah total kebutuhan inverter, In $n_{\text {rateout }}$ adalah kapasitas output inverter dalam satuan $\mathrm{kW}$.

Setelah rooftop PV untuk kedua villa dirancang maka akan disimulasikan dengan PVSyst untuk mendapatkan gambaran tentang unjuk kerja sistem PV tersebut dilihat dari produksi energi bulanan dan tahunan. PVSyst merupakan paket software yang digunakan dalam perancangan dan analisis unjuk kerja dari suatu sistem PV secara lengkap. PVSyst yang digunakan dalam penelitian ini adalah PVSyst V6.70. Data meteorologi yang digunakan pada PVSyst penelitian ini adalah Meteonorm V7.2 (2017) [20].

Untuk mengetahui kelayakan ekonomi dari pembangunan sistem PV atap bangunan ini maka akan dilakukan analisa investasi. Untuk itu berbagai komponen investasi akan diperhitungkan antara lain: biaya komponen sistem PV (biaya investasi awal, biaya operasi dan pemeliharaan, biaya penggantian), waktu pengembalian investasi dan kelayakan investasi [21][22].

Biaya komponen sistem PV akan dihitung menggunakan metode Life Cycle Cost ( $L C C$ ) dengan persamaan berikut [22]:

$$
L C C=C+M_{p w}+R_{p w}
$$

Dimana, $C$ adalah biaya investasi awal sistem PV, $M_{p w}$ adalah biaya operasi dan pemeliharaan sistem PV selama umur investasi yang dapat dihitung dengan persamaan berikut [22]:

$$
M_{p w}=M\left(\frac{1+i}{1+d}\right)\left[\frac{1-\left(\frac{1+i}{1+d}\right)^{n}}{1-\left(\frac{1+i}{1+d}\right)}\right]
$$

Dimana, $n$ adalah umur investasi, $d$ adalah suku bunga Bank, $i$ adalah nilai inflasi dan $M$ adalah biaya operasi dan pemeliharaan sistem PV per tahun yang dapat dihitung dengan persamaan berikut [22]:

$$
M=\operatorname{Perc}_{O \& M} x C
$$

Dimana, Perc ${ }_{O \& M}$ adalah persentase operasi dan pemeliharaan.

Sedangkan, $R_{p w}$ adalah biaya penggantian komponen sistem PV selama umur investasi yang dapat dihitung dengan persamaan berikut [22]:

$$
R_{p w}=R\left(\frac{1+i}{1+d}\right)^{n}
$$

Dengan, $R$ adalah total biaya komponen (inverter) dannadalah tahun penggantian komponen.

Waktu pengembalian investasi akan ditentukan dengan metode Payback Period $(P B P)$ yang dapat dihitung dengan persamaan berikut [21]:

$$
P B P=\frac{V L_{i}}{N C F}
$$

Atau,

$$
P B P=\frac{L C C}{E_{\text {save }}}
$$

Dimana, $V L_{i}$ adalah nilai investasi, $N C F$ adalah aliran kas bersih. Sedangkan, potensi penghematan dapat dihitung dengan persamaan berikut [22]:

$$
E_{\text {save }}=E_{\text {price }} x A k W h
$$

Dimana, $E_{\text {save }}$ adalah penghematan energi menggunakan PV, $E_{\text {price }}$ adalah harga energi, $A k W h$ adalah total energi tahunan yang dihasilkan oleh sistem PV dalam satuan kWh.

Menentukan kelayakan investasi digunakan metode Net Present Value (NPV) dengan persamaan berikut [22]:

$$
N P V=\sum_{t=1}^{n} P V N C F t-C
$$

Dimana, PVNCFt adalah NCFt $x$ DFt, dengan NCFt adalah (kas masuk-kas keluar) dan $D F t$ adalah faktor diskonto yang dapat dihitung dengan persamaan [22]:

$$
D F t=\frac{1}{(1+d)^{t}}
$$

Dimana,tadalah masa hidup investasi.

\section{HASIL DAN PEMBAHASAN}

\section{A. Audit Energi}

Untuk mengetahui sistem kelistrikan dan pola konsumsi energi listrik pada masing-masing villa, maka dilakukan audit energi pada lokasi penelitian pada Juli 2017. Metode audit energi dilakukan dengan mengacu pada pedoman teknis audit 
energi. Data-data yang dikumpulkan meliputi jenis alat/peralatan yang digunakan, spesifikasi teknis peralatan dan pola/waktu operasi peralatan. Waktu operasi peralatan pada masing-masing villa ditentukan berdasarlan rata-rata hasil observasi pemakaian per hari pada Juli 2017.

Hasil audit energi pada masing-masing villa disajikan pada Tabel I dan II. Sementara itu, konsumsi energi riil yang dibayarkan oleh masing-masing villa ke PLN berdasarkan data yang diberikan oleh pihak manajemen villa disajikan pada Gambar 4.

TABEL I

AUDIT ENERGI PRIVATE VILLA

\begin{tabular}{|c|c|c|c|c|c|}
\hline Beban & $\begin{array}{c}\text { Daya } \\
\text { (Watt) }\end{array}$ & Total & $\begin{array}{c}\text { TotalDaya } \\
\text { (Watt) }\end{array}$ & $\begin{array}{c}\text { Waktu } \\
\text { Operasi } \\
\text { (h) }\end{array}$ & $\begin{array}{c}\text { Energi } \\
\text { (Wh) }\end{array}$ \\
\hline \multicolumn{6}{|l|}{ Penerangan } \\
\hline Led & 4 & 2 & 8 & 3 & 24 \\
\hline Led & 6 & 24 & 144 & 3 & 432 \\
\hline Led & 7 & 374 & 2.618 & 10 & 26.180 \\
\hline $\mathrm{Plc}$ & 11 & 68 & 748 & 6 & 4.488 \\
\hline Sportlight & 7 & 98 & 686 & 4 & 2.744 \\
\hline Pendant & 50 & 3 & 150 & 3 & 450 \\
\hline Halogen & 50 & 9 & 450 & 3 & 1.350 \\
\hline Halogen & 6 & 20 & 120 & 3 & 360 \\
\hline Halogen & 7 & 116 & 812 & 3 & 2.436 \\
\hline TV 24 inch & 75 & 1 & 75 & 2 & 150 \\
\hline TV 32 inch & 115 & 2 & 230 & 4 & 920 \\
\hline Exhaust fan & 39 & 2 & 78 & 0,10 & 8 \\
\hline Exhaust fan & 59 & 2 & 118 & 0,10 & 12 \\
\hline Exhaust fan & 35 & 25 & 875 & 0,10 & 88 \\
\hline $\mathrm{AC} 2.5 \mathrm{pk}$ & 1.910 & 4 & 7.640 & 4 & 30.560 \\
\hline AC $3 \mathrm{pk}$ & 2.840 & 2 & 5.680 & 2 & 11.360 \\
\hline AC $5 \mathrm{pk}$ & 5.100 & 7 & 35.700 & 2 & 71.400 \\
\hline AC $5.5 \mathrm{pk}$ & 5.800 & 4 & 23.200 & 2 & 46.400 \\
\hline $\begin{array}{l}\text { Booster } \\
\text { pump }\end{array}$ & 1.100 & 2 & 2.200 & 2 & 4.400 \\
\hline $\begin{array}{l}\text { Transfer } \\
\text { pump }\end{array}$ & 1.100 & 1 & 1.100 & 2 & 2.200 \\
\hline $\begin{array}{l}\text { Submersible } \\
\text { pump }\end{array}$ & 550 & 3 & 1.650 & 6 & 9.900 \\
\hline Pool pump & 1.000 & 3 & 3.000 & 6 & 18.000 \\
\hline Pool pump & 1.400 & 2 & 2.800 & 8 & 22.400 \\
\hline Microwave & 400 & 1 & 400 & 0,25 & 100 \\
\hline Refrigerator & 50 & 3 & 150 & 12 & 1.800 \\
\hline Computer & 50 & 2 & 100 & 9 & 900 \\
\hline \multicolumn{3}{|l|}{ Total } & 90.732 & & 259.061 \\
\hline
\end{tabular}

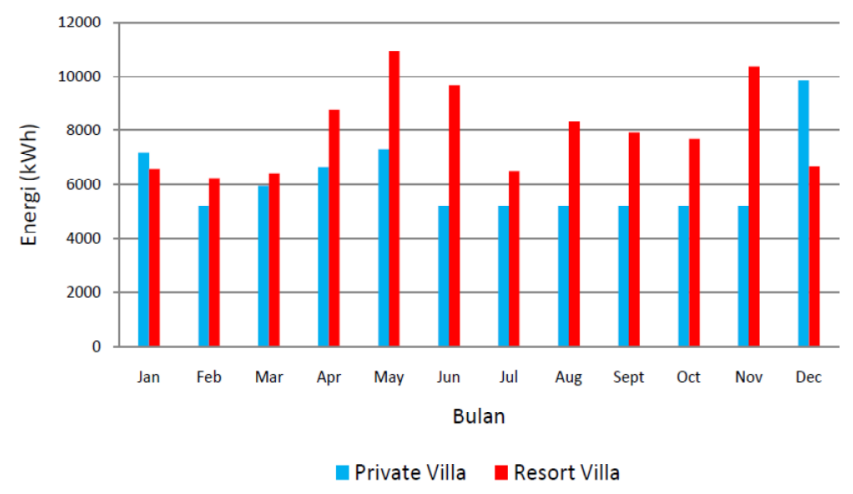

I Kadek Sumariana : Penilaian Potensi Akomodasi Tipe...
Gambar 4 : Grafik energi dari PLN

Dapat dilihat pada Tabel I bahwa total daya peralatan atau power demand di villa sangat besar, namun pada kenyataanya karena pengoperasian peralatan tersebut tidak terjadi secara bersamaan. Sehingga plafon daya villa yang sebesar $131 \mathrm{kVA}$ masih mampu memenuhi kebutuhan villa.

TABEL II

AUDIT ENERGI RESORT VILLA

\begin{tabular}{|c|c|c|c|c|c|}
\hline Beban & $\begin{array}{c}\text { Daya } \\
\text { (Watt) }\end{array}$ & Total & $\begin{array}{l}\text { Total Daya } \\
\text { (Watt) }\end{array}$ & $\begin{array}{c}\text { Waktu } \\
\text { Operasi } \\
(\text { h) }\end{array}$ & $\begin{array}{c}\text { Energi } \\
\text { (Wh) }\end{array}$ \\
\hline \multicolumn{6}{|l|}{ Penerangan } \\
\hline Led & 9 & 48 & 432 & 6 & 2.592 \\
\hline Plc & 36 & 47 & 1.692 & 5 & 8.460 \\
\hline Sportlight & 50 & 34 & 1.700 & 6 & 10.200 \\
\hline Halogen & 50 & 188 & 9.400 & 10 & 94.000 \\
\hline Halogen & 150 & 19 & 2.850 & 4 & 11.400 \\
\hline $\mathrm{TL}$ & 50 & 2 & 100 & 2 & 200 \\
\hline TV & 115 & 10 & 1.150 & 4 & 4.600 \\
\hline $\mathrm{AC}$ & 1.500 & 8 & 12.000 & 4 & 48.000 \\
\hline Celling fan & 150 & 18 & 2.700 & 3 & 8.100 \\
\hline Water heater & 2.500 & 3 & 7.500 & 1 & 7.500 \\
\hline Water heater & 1.500 & 2 & 3.000 & 1 & 3.000 \\
\hline $\begin{array}{l}\text { Booster } \\
\text { pump }\end{array}$ & 1.100 & 1 & 1.100 & 3 & 3.300 \\
\hline Pool pump & 1.400 & 3 & 4.200 & 12 & 50.400 \\
\hline Microwave & 400 & 1 & 400 & 0,45 & 180 \\
\hline Mixer & 800 & 1 & 800 & 0,45 & 360 \\
\hline Blender & 1.100 & 1 & 1.100 & 0,45 & 495 \\
\hline Refrigerator & 50 & 2 & 100 & 12 & 1.200 \\
\hline Refrigerator & 150 & 1 & 150 & 12 & 1.800 \\
\hline Computer & 50 & 2 & 100 & 5 & 500 \\
\hline \multicolumn{3}{|l|}{ Total } & 50.474 & & 256.287 \\
\hline
\end{tabular}

Dari Gambar 4 dapat dilihat bahwa konsumsi energi pada private villa berubah-ubah setiap bulan. Perbedaan konsumsi energi ini dipengaruhi oleh jumlah hari tinggal/kunjungan pemilik villa setiap bulannya pada kasus private villa. Sedangkan pada kasus resort villa, fluktuasi energi ini disebabkan oleh jumlah tamu/wisatawan yang menginap atau melakukan kegiatan khusus seperti pesta pernikahan. Total konsumsi energi per tahun pada private villa adalah sebesar $73.675 \mathrm{kWh}$ dan resort villa sebesar $96.214 \mathrm{kWh}$, dengan ratarata konsumsi energi minimum per bulan pada kedua villa adalah $5.748 \mathrm{kWh}$ dan maksimum sebesar $10.409 \mathrm{kWh}$.

Jika merujuk pada target bauran energi 2025 yang disebutkan dalam RUEN, bahwa komposisi EBT adalah sebesar 23\% dari total konsumsi energi nasional. Jika prinsip ini diterapkan pada villa dan karena satu-satunya sumber energi yang digunakan villa adalah energi listrik, maka agar memenuhi target EBT 23\% tersebut, villa harus mampu memenuhi $23 \%$ energi listriknya yang berasal dari sumber energi terbarukan. Dalam konteks penelitian ini yang mengusulkan solar PV maka kapasitas PV yang didesain harus mampu menghasilkan energi untuk memenuhi $23 \%$ dari kebutuhan energi villa. Berdasarkan pendekatan ini maka sistem PV harus mampu menghasilkan energi sebesar 59,6 $\mathrm{kWh}$ pada private villa dan $59 \mathrm{kWh}$ pada resort villa.

$$
\text { p-ISSN:1693 - 2951; e-ISSN: 2503-2372 }
$$


Untuk mengetahui potensi energi matahari di lokasi villa maka dilakukan pengukuran iradiasi matahari. Iradiasi ini diukur dengn portable pyranometer. Hasil rata-rata iradiasi matahari pada lokasi villa yang diukur pada Juli 2017, disajikan pada Gambar 5. Untuk mengetahui bagaimana power demand/kurva beban dari villa dan potensi pembangkitan daya listrik sistem PV telah dilakukan pengukuran terhadap fluktuasi daya di masing-masing villa dan hasilnya disajikan pada Gambar 5.

Rata-rata pemakaian daya listrik per hari pada masingmasing villa ditentukan dengan melakukan pengukuran menggunakan tang ampere pada bulan Juli 2017. Beban puncak pada masing-masing villa terjadi pada jam 19.00, karena pada saat itu hampir semua beban yang berupa penerangan sedang dihidupkan. Sedangkan pada siang hari, dari jam 10.00-12.00 dipengaruhi oleh peralatan listrik yang digunakan seperti peralatan dapur untuk mempersiapkan makan siang dan penggunaan Air Conditioner (AC) karena panasnya cuaca pada siang hari.

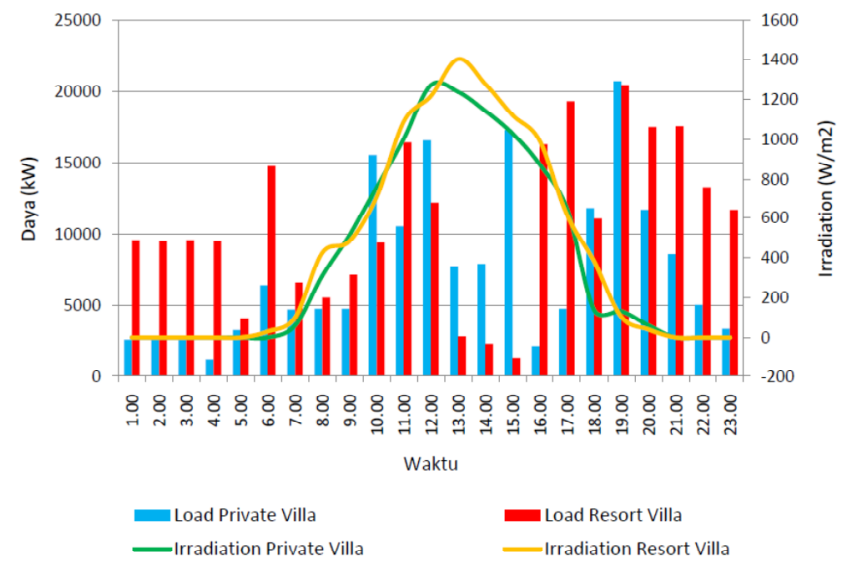

Gambar 5 : Daya beban dan iradiasi matahari

\section{B. Desain Rooftop PV}

Sistem grid-connected PV yang akan dirancang terdiri dari modul PV dan grid inverter seperti disajikan pada Gambar 6. Daya yang dihasilkan oleh modul PV akan disalurkan langsung kebeban melalui grid inverter. Sistem gridconnected PV dan PLN bekerja pararel. Apabila sistem PV tidak menghasilkan daya, misalnya pada malam hari atau cuaca hujan disiang hari, maka PLN akan mensuplai listrik ke beban.

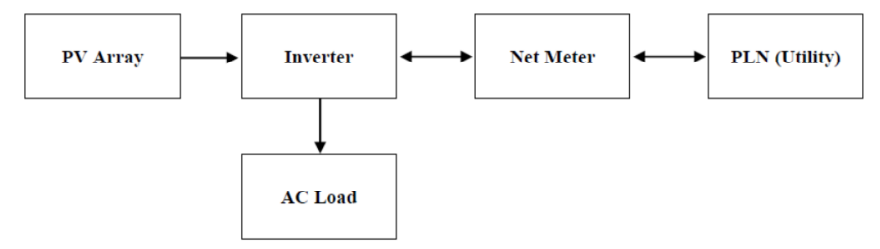

Gambar 6 : Skematik grid-connected PV pada villa

Berdasarkan Tabel I dan II hasil audit energi pada masingmasing villa diketahui, besarnya konsumsi energi harian pada private villa adalah $259 \mathrm{kWh} /$ hari dan resort villa sebesar 256 kWh/hari. Sedangkan, besarnya energi listrik yang akan disuplai oleh sistem PV adalah 23\% dari pemakaian energi harian tersebut. Maka, 23\% konsumsi energi pada masingmasing villa adalah 59,6 kWh pada private villa dan $59 \mathrm{kWh}$ pada resort villa.

TABEL III

KEBUTUHAN ENERGI VILLA

\begin{tabular}{|c|r|rr|}
\hline Villa & $\begin{array}{c}\text { Konsumsi Energi } \\
(\mathbf{k W h})\end{array}$ & \multicolumn{2}{|c|}{$\begin{array}{c}\text { 23\% Kebutuhan Energi } \\
(\mathbf{k W h})\end{array}$} \\
\hline Private Villa & 259 & & 59,6 \\
\hline Resort Villa & 256 & & 59 \\
\hline
\end{tabular}

Dalam perancangan sistem PV diperlukan data radiasi matahari dari lokasi masing-masing villa. Data radiasi matahari pada penelitian ini diestimasi dari data meteorologi dalam PVSyst V6.70 berdasarkan lokasi masing-masing villa yaitu private villa yang terletak dikoordinat $-8.83^{\circ} \mathrm{S}, 115.08^{0} \mathrm{E}$ dan resort villa yang terletak dikoordinat $-8.84^{0} \mathrm{~S}, 115.20^{0} \mathrm{E}$ [20]. Potensi energi matahari untuk kedua lokasi disajikan pada Gambar 7.

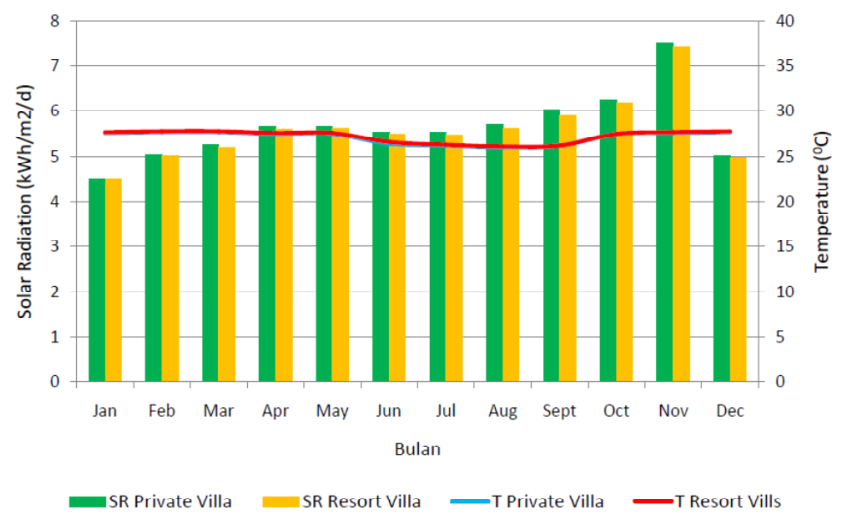

Gambar 7 : Radiasi matahari pada villa

Menentukan faktor generasi panel bertujuan untuk mendapatkan kapasitas sistem PV yang diharapkan, dengan radiasi matahari yang berbeda disetiap lokasi [18]. Untuk private villa rata-rata radiasi adalah $5,64 \mathrm{kWh} / \mathrm{m}^{2} / \mathrm{d}$ dan resort villa $5,59 \mathrm{kWh} / \mathrm{m}^{2} / \mathrm{d}$ sesuai Gambar 7. Sehingga, faktor generasi panel pada private villa adalah 5,64 dan resort villa 5,59 dengan Persamaan (3).

Kapasitas energi output sistem PV yang dirancang adalah total konsumsi energi harian dari masing-masing villa yaitu $59,6 \mathrm{kWh}$ untuk private villa dan $59 \mathrm{kWh}$ untuk resort villa. Sedangkan energi yang diperlukan untuk mengkompensasi rugi-rugi sistem PV adalah sebesar 30\% [18]. Sehingga, total kebutuhan energi sistem PV pada private villa dengan Persamaan (4) adalah 77,5 kWh dan resort villa 76,7 kWh. Maka, kapasitas daya sistem PV pada masing-masing villa yang dihitung dengan Persamaan (2) adalah sama bagi kedua villa yaitu $13,7 \mathrm{kWp}$.

Pemilihan modul PV didasarkan atas ketersediannya di Indonesia dan dari survei yang telah dilakukan digunakan modul surya dengan output $330 \mathrm{Wp}$ buatan Q-Cells. Spesifikasi yang lengkap dari modul PV disajikan pada Tabel IV [23]. Total kebutuhan modul PV pada masing-masing villa 
sesuai dengan Persamaan (5) adalah 42 modul pada kedua villa.

TABEL IV

SPESIFIKASI MODUL PV

\begin{tabular}{|l|r|}
\hline \multicolumn{1}{|c|}{ Parameter } & \multicolumn{1}{|c|}{ Informasi } \\
\hline Manufacturer & Q-Cells \\
\hline Model Number & Q. POWER L_G5 2 \\
\hline Rated Power (W) & 330 \\
\hline Max. Power Voltage (V) & 37,7 \\
\hline Max. Current (A) & 8,76 \\
\hline Open Circuit Voltage (V) & 46,1 \\
\hline Short Circuit Current (A) & 9,30 \\
\hline Module Efficiency (\%) & 16,9 \\
\hline Weight (Kg) & 22,5 \\
\hline Dimension (mm) & $1.960 \times 991 \times 35$ \\
\hline
\end{tabular}

Kapasitas inverter yang dipilih berkaitan dengan kapasitas sistem PV pada masing-masing villa, dengan toleransi $25 \%$ $30 \%$ lebih besar dari kapasitas sistem PV [18]. Kapasitas inverter pada masing-masing villa setelah dihitung dengan Persamaan (7) adalah 17,8 kW pada kedua villa.

Inverter yang diusulkan pada penelitian ini adalah inverter Solis-6K 3 fase dimana spesifikasi teknisnya disajikan pada Tabel V [24]. Pemilihan inverter ini didasari atas ketersediannya di Indonesia dan statusnya sudah memenuhi persyaratan koneksi grid seperti EN50438, AS4777, VDE0126, dan IEC61727, serta standar keamanan dan EMC. Berdasarkan perhitungan maka total jumlah inverter sesuai dengan Persamaan (8) adalah 3-unit untuk masing-masing villa.

TABEL V

SPESIFIKASI INVERTER

\begin{tabular}{|l|r|}
\hline \multicolumn{1}{|c|}{ Parameter } & \multicolumn{2}{c|}{ Informasi } \\
\hline Manufacturer & SOLIS \\
\hline Model Number & Solis-6K \\
\hline Max. Input Power (W) & 6.900 \\
\hline Output Power (W) & 6.000 \\
\hline Max. Input Voltage (V) & 1.000 \\
\hline Output Voltage (V) & $313-470$ \\
\hline Output Current (A) & 10 \\
\hline Efficiency (\%) & 98,2 \\
\hline
\end{tabular}

Spesifikasi komponen utama sistem PV berdasarkan hasil perhitungan untuk kedua villa disajikan pada Tabel VI.

TABEL VI

KOMPONEN SISTEM PV

\begin{tabular}{|l|r|r|}
\hline \multicolumn{1}{|c|}{ Deskripsi } & Private Villa & Resort Villa \\
\hline Kapasitas Sistem (kWp) & 13,7 & 13,7 \\
\hline Modul PV (Wp) & 330 & 330 \\
\hline Total Modul & 42 & 42 \\
\hline Inverter (kW) & 6 & 6 \\
\hline Total Inverter & 3 & 3 \\
\hline
\end{tabular}

Luas area atap bangunan yang dibutuhkan untuk pemasanganmodul PV dari sistem grid-connected PV pada masing-masing villa didasarkan pada TabelIV dan VI, adalah I Kadek Sumariana : Penilaian Potensi Akomodasi Tipe...
$82 \mathrm{~m}^{2}$ untuk setiap villa yang dihitung dengan Persamaan (6) [19]. Pemasangan modul PVpada atap bangunan masingmasing villa dibandingkan dengan luas total atap bangunan villa adalah sebesar $6,15 \%$ dan $11,36 \%$, seperti disajikan pada Tabel VII. Hasil ini menunjukkan bahwa, jika dilakukan penambahan kapasitas dari sistem rooftop PV, hal ini masih bisa dilakukan karena luas atap yang tersedia masih banyak.

TABEL VII

RASIO PEMANFAATAN ATAP

\begin{tabular}{|l|r|r|r|}
\hline \multicolumn{1}{|c|}{ Villa } & $\begin{array}{c}\text { Luas Total } \\
\text { Atap }\left(\mathbf{m}^{\mathbf{3}}\right)\end{array}$ & $\begin{array}{c}\text { Total Area } \\
\text { Array }\left(\mathbf{m}^{\mathbf{2}}\right)\end{array}$ & $\begin{array}{c}\text { Rasio } \\
\text { Pemanfaatan } \\
\text { Atap (\%) }\end{array}$ \\
\hline Private Villa & 1.333 & 82 & 6,15 \\
\hline Resort Villa & 722 & 82 & 11,36 \\
\hline
\end{tabular}

\section{Estimasi Produksi Energi}

Hasil rancangan sistem PV pada masing-masing villa disimulasikan menggunakan PVSyst V6.70. Data input yang diperlukan dalam simulasi ini disajikan pada Tabel VI. Hasil simulasi produksi energi dari sistem grid-connected PV pada villa dapat dilihat pada Tabel VIII.

TABEL VIII

HASIL SIMULASI SISTEM PV

\begin{tabular}{|c|c|c|}
\hline \multirow{2}{*}{ Bulan } & \multicolumn{2}{|c|}{ E_Grid (kWh) } \\
\cline { 2 - 3 } & Private Villa & Resort Villa \\
\hline Jan & 1.281 & 1.281 \\
\hline Feb & 1.400 & 1.400 \\
\hline Mar & 1.757 & 1.741 \\
\hline Apr & 2.051 & 2.035 \\
\hline May & 2.373 & 2.357 \\
\hline Jun & 2.385 & 2.361 \\
\hline Jul & 2.401 & 2.379 \\
\hline Aug & 2.268 & 2.228 \\
\hline Sept & 2.067 & 2.021 \\
\hline Oct & 1.949 & 1.920 \\
\hline Nov & 1.965 & 1.955 \\
\hline Dec & 1.412 & 1.400 \\
\hline Annual & $\mathbf{2 3 . 3 0 9}$ & $\mathbf{2 3 . 0 7 8}$ \\
\hline
\end{tabular}

Persentase energi yang dihasilkan sistem PV, dibandingkan dengan $23 \%$ konsumsi energi riil yang dibayarkan ke PLN pada masing-masing villa seperti disajikan pada Gambar 4, disajikan pada Gambar 8 dan 9.

Produksi energi per tahun sistem PV adalah $1.942 \mathrm{kWh}$ dan energi riil dari PLN sebesar $1.412 \mathrm{kWh}$ pada private villa. Sedangkan pada resort villa, produksi sistem PV sebesar 1.923 $\mathrm{kWh}$ dan PLN sebesar $1.844 \mathrm{kWh}$. Perbandingan rata-rata produksi sistem PV dan PLN pada kedua villa adalah sebesar 120\%. Pada bulan Desember dan Januari, sistem PV tidak mampu memenuhi kebutuhan energi villa. Hal itu dipengaruhi oleh rendahnya intensitas radiasi matahari pada bulan tersebut karena musim penghujan [25], dan tingginya tingkat penggunaan kedua villa menjelang akhir tahun. Sedangkan pada bulan Juni dan Juli, output sistem PV sangat tinggi yang disebabkan oleh tingginya intesitas radiasi matahari pada

p-ISSN:1693 - 2951; e-ISSN: 2503-2372 
bulan tersebut karena musim kemarau [25], dan rendahnya tingkat penggunaan energi kedua villa.

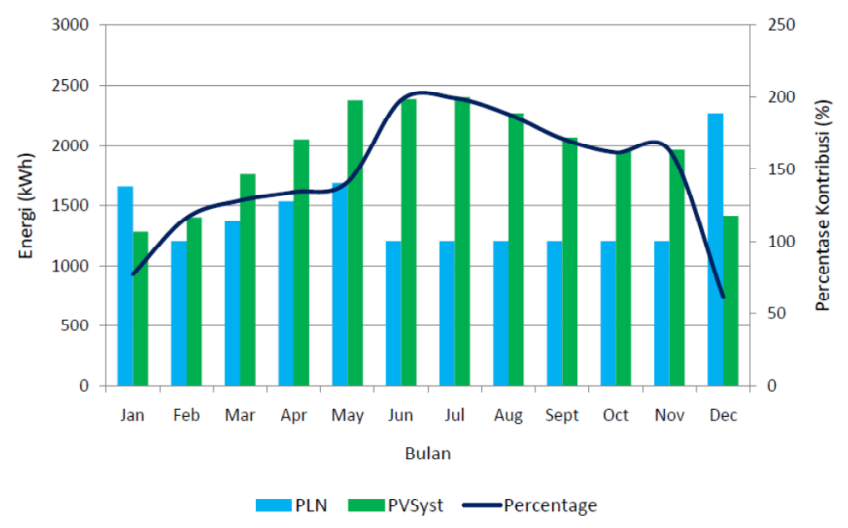

Gambar 8 : Perbandingan persentase energi private villa

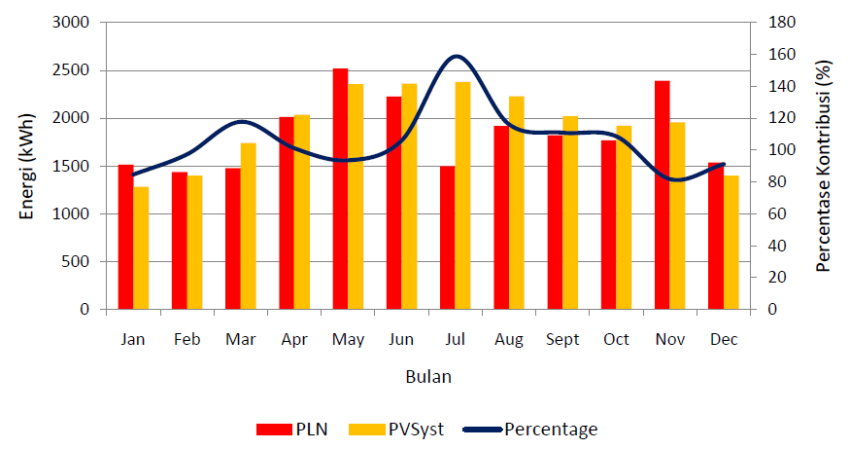

Gambar 9 : Perbandingan persentase energi resort villa

Jika diasumsikan seluruh akomodasi vila di Bali memanfaatkan sistem PV berkapasitas 13,7 kWp dengan pemakaian energi perhari sebesar $59 \mathrm{kWh}$ dan jumlah seluruh villa sebanyak 2.542-unit, maka dalam sehari akomodasi pariwisata villa mampu menyumbang penghematan energi sebesar $150 \mathrm{MWh} /$ hari atau 54.750 MWh/tahun. Sedangkan potensi total kapasitas PV untuk seluruh villa adalah 13,7 kWp * 2.542 sebesar 34,8 MWp.

\section{Analisis Investasi}

Besarnya komponen investasi awal dari sistem PV yang dirancang pada private villa dan resort villa dapat dilihat pada Tabel IX [26].

TABEL IX

BIAYA INVESTASI AWAL

\begin{tabular}{|c|c|c|c|}
\hline Komponen & Harga Unit (Rp) & Jumlah & Total (Rp) \\
\hline Module PV $330 \mathrm{Wp}$ & 3.465 .000 & 42 & 145.530 .000 \\
\hline Inverter $6 \mathrm{kw}$ & 28.000 .000 & 3 & 84.000 .000 \\
\hline Accessory Installation: & \multirow{4}{*}{8.300 .000} & \multirow{4}{*}{1} & \multirow{4}{*}{8.300 .000} \\
\hline Cable \& Connector Set & & & \\
\hline Box Inverter & & & \\
\hline Rooftop Mounting & & & \\
\hline $\begin{array}{l}\text { Installation, Testing \& } \\
\text { Commissioning }\end{array}$ & 5.000 .000 & 1 & 5.000 .000 \\
\hline Total Investasi & & & 242.830 .000 \\
\hline
\end{tabular}

Biaya operasional dan pemeliharan per tahun untuk sistem PV, umumnya diasumsikan sebesar $1 \%$ dari total biaya investasi awal [22]. Adapun biaya operasional dan pemeliharaan per tahun $(M)$ adalah Rp. 2.428.300 dengan Persamaan (11). Sedangkan, total biaya pemeliharaan sistem PV selama umur investasi $\left(M_{p w}\right)$ adalah Rp. 45.745.098 yang dihitung dengan Persamaan (10). Umur investasi diasumsikan selama 25 tahun yang mengacu pada datasheet modul PV yang dipilih [23]. Sedangkan, $d$ sebesar $6 \%$ berdasarkan suku bunga Bank Indonesia (BI) tahun 2018 dan $i$ sebesar $3.61 \%$ berdasarkan inflasi tahun 2018 [27].

Komponen sistem PV seperti inverter memiliki usia operasi lebih pendek dari pada usia modul PV, yaitu selama 5 tahun sesuai data pada datasheet, standard warranty komponen [24]. Total biaya penggantian inverter diperoleh dengan mengalikan jumlah inverter dan harga inverter yang digunakan berdasarkan data tahun 2018 [26], suku bunga bank dan inflasi tahun 2018 [27]. Maka total penggantian inverter selama umur investasi 25 tahun adalah sebanyak empat kali yaitu pada tahun ke-6, 12, 18, 24. Adapun total biaya penggantian komponen sistem PV selama umur investasi $\left(R_{p w}\right)$ dihitung dengan Persamaan (12) adalah $R_{p w}$ inverter tahun ke-6 Rp. 73.257.844, tahun ke-12 Rp. 63.889.426, tahun ke-18 Rp. 55.719.067, tahun ke-24 Rp. 48.593.556. Total biaya penggantian inverter selama umur investasi $\left(R_{p w}\right)$ adalah Rp. 241.459.893. Dimana, $R$ adalah total biaya inverter sebesar $\mathrm{Rp}$. 84.000.000 sesuai Tabel IX dan $i, d$, telah didefinisikan sebelumnya, sedangkan $n$ adalah tahun penggantian yaitu tahun ke-6, 12, 18, 24. Sehingga, besarnya biaya komponen PV (LCC) dapat dihitung dengan Persamaan (9) adalah Rp. 530.034.991.

Total energi tahunan yang dihasilkan oleh sistem PV pada private villa adalah $23.309 \mathrm{kWh}$ dan resort villa sebesar 23.078 kWh sesuai hasil simulasi pada Tabel VIII. Total energi yang dihasilkan oleh sistem PV ini diasumsikan akan menjadi potensi penghematan energi pada masing-masing villa [22]. Selama ini kedua villa membayarkan tagihan energi ke PLN dengan klasifikasi tarif R-1/1.300 VA dengan harga energi pada tahun 2018 sebesar Rp. 1.467/kWh [28]. Sehingga, potensi penghematan energi pada masing-masing villa adalah Rp. 34.194.303/tahun pada private villa dan $\mathrm{Rp}$. 33.855.426/tahun pada resort villa dihitung dengan Persamaan (14).

Teknik analisis kelayakan investasi yang akan digunakan adalah Net Present Value (NPV). Dengan kriteria : jika $N P V\rangle$ 0 maka investasi dianggap layak, dan jika $N P V<0$ maka investasi dianggap tidak layak [22]. Untuk faktor diskonto ( DFt) dihitung dengan Persamaan (16) dimana, $d$ telah didefinisikan sebelumnya dan $t$ masa hidup investasi dari 1 sampai 25 tahun. Sedangkan, NCFt ditentukan berdasarkan ketentuan sebagai berikut: Kas masuk adalah hasil dari potensi penghematan menggunakan sistem PV. Sedangkan, Kas keluar terdiri dari: 1) biaya operasional dan pemeliharaan per tahun, dan 2) total biaya penggantian inverter. Jika semua nilai tersebut ditabulasikan, maka nilai $N P V$ dapat ditentukan seperti pada Tabel X. 
TABEL $X$

ANALISIS KELAYAKAN INVESTASI SISTEM PV PRIVATE VILLA

\begin{tabular}{|c|c|c|c|c|c|c|c|}
\hline \multirow[b]{2}{*}{ Tahun } & \multirow{2}{*}{$\begin{array}{c}\text { Kas Masuk } \\
\mathbf{E}_{\text {save }}\end{array}$} & \multicolumn{2}{|c|}{ Kas Keluar } & \multirow[b]{2}{*}{ NCFt } & \multirow[b]{2}{*}{ DFt 6\% } & \multirow[b]{2}{*}{ PVNCFt } & \multirow[b]{2}{*}{ Commulative $\sum \mathrm{NCFt}^{*} \mathrm{DFt}$} \\
\hline & & $\mathbf{O} \& \mathbf{M}$ & Inverter & & & & \\
\hline 0 & - & - & - & - & 1,000 & - & \\
\hline 1 & 34.194 .303 & 2.428 .300 & - & 31.766 .003 & 0,943 & 29.967 .927 & 29.967 .927 \\
\hline 2 & 34.194 .303 & 2.428 .300 & - & 31.766 .003 & 0,890 & 28.271 .630 & 58.239 .557 \\
\hline 3 & 34.194 .303 & 2.428 .300 & - & 31.766 .003 & 0,840 & 26.671 .349 & 84.910 .906 \\
\hline 4 & 34.194 .303 & 2.428 .300 & - & 31.766 .003 & 0,792 & 25.161 .650 & 110.072 .555 \\
\hline 5 & 34.194 .303 & 2.428 .300 & - & 31.766 .003 & 0,747 & 23.737 .405 & 133.809 .961 \\
\hline 6 & 34.194 .303 & 2.428 .300 & 84.000 .000 & -52.233 .997 & 0,705 & -36.822 .907 & 96.987 .054 \\
\hline 7 & 34.194 .303 & 2.428 .300 & - & 31.766 .003 & 0,665 & 21.126 .206 & 118.113 .260 \\
\hline 8 & 34.194 .303 & 2.428 .300 & - & 31.766 .003 & 0,627 & 19.930 .383 & 138.043 .643 \\
\hline 9 & 34.194 .303 & 2.428 .300 & - & 31.766 .003 & 0,592 & 18.802 .248 & 156.845 .892 \\
\hline 10 & 34.194 .303 & 2.428 .300 & - & 31.766 .003 & 0,558 & 17.737 .970 & 174.583 .862 \\
\hline 11 & 34.194 .303 & 2.428 .300 & - & 31.766 .003 & 0,527 & 16.733 .934 & 191.317 .796 \\
\hline 12 & 34.194 .303 & 2.428 .300 & 84.000 .000 & -52.233 .997 & 0,497 & -25.958 .696 & 165.359 .100 \\
\hline 13 & 34.194 .303 & 2.428 .300 & - & 31.766 .003 & 0,469 & 14.893 .142 & 180.252 .242 \\
\hline 14 & 34.194 .303 & 2.428 .300 & - & 31.766 .003 & 0,442 & 14.050 .134 & 194.302 .375 \\
\hline 15 & 34.194 .303 & 2.428 .300 & - & 31.766 .003 & 0,417 & 13.254 .843 & 207.557 .219 \\
\hline 16 & 34.194 .303 & 2.428 .300 & - & 31.766 .003 & 0,394 & 12.504 .569 & 220.061 .788 \\
\hline 17 & 34.194 .303 & 2.428 .300 & - & 31.766 .003 & 0,371 & 11.796 .763 & 231.858 .551 \\
\hline 18 & 34.194 .303 & 2.428 .300 & 84.000 .000 & -52.233 .997 & 0,350 & -18.299 .857 & 213.558 .694 \\
\hline 19 & 34.194 .303 & 2.428 .300 & - & 31.766 .003 & 0,331 & 10.499 .077 & 224.057 .772 \\
\hline 20 & 34.194 .303 & 2.428 .300 & - & 31.766 .003 & 0,312 & 9.904 .790 & 233.962 .561 \\
\hline 21 & 34.194 .303 & 2.428 .300 & - & 31.766 .003 & 0,294 & 9.344 .141 & 243.306 .703 \\
\hline 22 & 34.194 .303 & 2.428 .300 & - & 31.766 .003 & 0,278 & 8.815 .228 & 252.121 .931 \\
\hline 23 & 34.194 .303 & 2.428 .300 & - & 31.766 .003 & 0,262 & 8.316 .253 & 260.438 .183 \\
\hline 24 & 34.194 .303 & 2.428 .300 & 84.000 .000 & -52.233 .997 & 0,247 & -12.900 .677 & 247.537 .506 \\
\hline 25 & 34.194 .303 & 2.428 .300 & - & 31.766 .003 & 0,233 & 7.401 .435 & 254.938 .942 \\
\hline
\end{tabular}

Berdasarkan hasil yang disajikan pada Tabel $\mathrm{X}$ diketahui bahwa pada akhir tahun ke-25, akumulasi nilai $\sum_{t=1}^{25} \mathrm{PVNCFt}$ $=$ Rp. 254.938.942. Sehingga untuk menentukan kriteria nilai NPV dapat ditentukan menggunakan Persamaan (15) adalah Rp. 12.108.942. Sedangkan, kriteria NPV resort villa dengan cara perhitungan yang sama menggunakan Persamaan (15) dan (16) adalah Rp. 7.776.956. Karena nilai $N P V$ pada private villa dan resort villa positif, maka sesuai dengan kriteria $N P V$ investasi dianggap layak.

Lamanya waktu pengembalian investasi sistem PV $(P B P)$ dihitung menggunakan Persamaan (13), hasilnya bahwa pengembalian investasi pada private villa adalah 15 tahun 5 bulan dan resort villa 15 tahun 7 bulan. Perbedaan waktu pengembalian investasi pada masing-masing villa dipengaruhi oleh total energi tahunan yang dihasilkan oleh sistem PV karena radiasi matahari yang berbeda disetiap lokasi, seperti ditunjukkan pada Tabel VIII. Masa pengembalian investasi yang cukup panjang disebabkan oleh harga jual energi relatif rendah, jika dibandingkan dengan harga jual energi di kawasan ASEAN [29].

\section{KESIMPULAN}

Paper ini telah mengkaji potensi teknis dan analisa ekonomi terkait pemanfaatan rooftop PV pada villa di Bali dalam I Kadek Sumariana : Penilaian Potensi Akomodasi Tipe... mendukung percepatan pembangunan PLTS untuk mencapai target $23 \%$ EBT pada tahun 2025. Kapasitas daya sistem gridconnected PV untuk memenuhi $23 \%$ kebutuhan energi perhari pada private villa dan resort villa adalah sebesar $13,7 \mathrm{kWp}$ dan luas atap yang digunakan untuk pemasangan rooftop PV dengan kapasitas ini hanya berkisar $11 \%$ dari seluruh atap bangunan villa.

Berdasarkan kajian ekonomi yang telah dilakukan, total investasi yang dibutuhkana adalah sebesar Rp. 242.830.000, dengan jangka waktu Payback Period pada private villa adalah 15 tahun 5 bulan dan resort villa adalah 15 tahun 7 bulan. Berdasarkan metode Net Present Value, investasi untuk sistem PV yang dirancang pada private villa dan resort villa bernilai positif atau layak. Lamanya $P B P$ secara umum akibat investasi awal yang masih mahal dan biaya penggantian inverter.

Hasil yang disajikan dalam paper ini diharapkan dapat membantu pemangku kepentingan energi terbarukan di Bali dalam melihat bagaimana komponen pariwisata khususnya villa-villa di Bali dapat membantu mempercepat tercapainya target PLTS di Bali. Pemerintah provinsi dan kabupaten sebagai regulator dapat mengeluarkan kebijakan dan regulasi berupa insentif baik berupa insentif pajak, finansial, maupun kemudahan-kemudahan lain seperti perijinan dan fasilitas lain

$$
\text { p-ISSN:1693 - 2951; e-ISSN: 2503-2372 }
$$


untuk sektor pariwisata yang ikut dalam pengembangan EBT di wilayahnya. Sementara, di sisi lain industri pariwisata dapat melihat bagaimana model pengembangan sebuah rooftop PV dan memahami unjuk kerja, kajian investasis, dan dampak lingkungan yang kemudian bisa dijadikan sebagai faktor penunjang pengembangan pariwisata hijau di Bali.

\section{REFERENSI}

[1] DEN, Buku Ketahanan Energi Indonesia, Sekretaris Jenderal Dewan Energi Nasional, Jakarta. 2015.

[2] Ngurah Rai Airport, "Bali Sun Radiation," Graph Bali sunshine data, Ngurah Rai Airport (source: Rescreen4): Lat: 8.8S; Lon: 115.2E, 2008.

[3] I. K. A. Setiawan, I. N. S. Kumara, I. W. Sukreyasa, "Analisis Unjuk Kerja Pembangkit Listrik Tenaga Surya (PLTS) Satu MWp Terinterkoneksi Jaringan Di Kayubihi, Bangli," Teknologi Elektro, Vol. 13 No. 1, 2014.

[4] I. N. S. Kumara, W. G. Ariastina, I. W. Sukerayasa and I. A. D. Giriantari, "On the potential and progress of renewable electricity generation in Bali," 2014 6th International Conference on Information Technology and Electrical Engineering (ICITEE), Yogyakarta, 2014, pp. 1-6.doi: 10.1109/ICITEED.2014.7007944.

[5] PT. PLN. (2016) Mulai Gunakan Mini LNG ke PLTDG Pesanggaran, PLN Mampu Hemat Biaya Pemeliharaan Rp 60 M per Tahun. [Online]. Available: $\quad$ https://www.pln.co.id/media/warta-pln/2016/06/mulaigunakan-mini-lng-ke-pltdg-pesanggaran-pln-mampu-hemat-biayapemeliharaan-rp-60-m-per-tahun.

[6] Disparda Provinsi Bali. (2018) Statistik Pariwisata Bali 2017. [Online]. Available: http://www.disparda.baliprov.go.id/id/Statistik4.

[7] BPS Provinsi Bali. (2018) Banyaknya kVA Tersambung dan kWh Terjual Menurut Jenis Pelanggan dan Area Pelayanan di Bali, 2017. [Online]. Available: https://bali.bps.go.id/statictable/2018/04/13/81/banyaknya-kvatersambung-dan-kwh-terjual-menurut-jenis-pelanggan-dan-areapelayanan-di-bali-2017.html.

[8] Pemerintah Provinsi Bali. (2013) Bali Clean dan Green Komitmen Jadikan Bali Bersih, Sehat, Nyaman dan Indah. [Online]. Available: http://www.baliprov.go.id/Bali-Clean-dan-Green-Komitmen-Jadikanbali-bersih--Sehat--Nyaman-dan-Indah.

[9] Biro Humas Provinsi Bali. (2018) Bali Clean and Green. [Online]. Available: http://www.birohumas.baliprov.go.id/index.php/fasilitas/21/BALICLEAN-\&-GREEN.

[10] M. Karagiorgas, T. Tsoutsos, V. Drosou, S. Pouffary, T. Pagano, G. L. Lara, J. M. M. Mendes, "HOTRES: renewable energies in the hotels. An extensive technical tool for the hotel industry," Elsevier Renewable and Sustainable Energy Reviews, Vol. 10. 2006.

[11] E. Michalena, Y. Tripanagnostopoulos, "Contribution of the solar energy in the sustainable tourism development of the Mediterranean islands," Elsevier Renewable Energy, Vol. 35. 2010.

[12] C. Chaoqun, "Researches on application of the renewable energy technologies in the development of low-carbon rural tourism," Elsevier Energy Procedia 5. 2011.

[13] A. H. A.M. Asif, M. T. Rahman, "Prospects of PV application in unregulated building rooftops in developing countries: A perspective from Saudi Arabia," Elsevier Energy and Buildings, Vol. 171. 2018.

[14] A. S. Cifuentes, S. Q. Garcia, "Economic feasibility of PV systems in hotels in Mexico," International Conference on Efficiency, Cost, Optimization, Simulation and Environmetal Impact of Energy System, Perugia. 2012.

[15] E. Marlina, Panduan Perancangan Bangunan Komersial, Andi Offset, Yogyakarta. 2008.

[16] Ditjen EBTKE. (2015) PLTS Rooftop Untuk Gedung Perkantoran. [Online]. Available: http://ebtke.esdm.go.id/post/2015/03/11/800/plts.rooftop.untuk.gedung .perkantoran.

[17] Kementrian Perindustrian, Pedoman Teknis Audit Energi Dalam Implementasi Konservasi Energi Dan Pengurangan Emisi $\mathrm{CO}_{2} \mathrm{Di}$ Sektor Industri (Fase 1), BPKIMI, Jakarta. 2011.
[18] Leonics. (2018) How to Design Solar PV System. [Online]. Available: http://www.leonics.com/support/article2_12j/articles2_12j_en.php.

[19] R. Khatri, "Design and Assessment of Solar PV Plant for Girls Hostel (GARGI) of MNIT University, Jaipur City: A Case Study," Elsevier Energy Reports, India. 2016.

[20] PVSyst V6.70 User Manual, PVSyst 6.70 Sofware, 2010.

[21] J. Arifin, Aplikasi Excel Untuk Perencanaan Bisnis (Busisness Plan), Elex Media Komputindo Gramedia, Jakarta. 2007.

[22] I. A. D. Giriantari, I. N. S. Kumara, D. A. Santiari, "Economic Cost Study of Photovoltaic Solar System for Hotel in Nusa Lembongan," International Conference on Smart Green Technology in Electrical andInformation Systems (ICSGTEIS), Kuta. 2014.

[23] "Q.POWER L-G5.2 315-335 datasheet," QCells, North Sydney, Australia.

[24] "Solis Three Phase Inverter datasheet," Solis, Zhejiang, China.

[25] BMKG. (2019) Prakiraan Musim Kemarau Tahun 2019 di Indonesia. [Online]. Available: https://www.bmkg.go.id/iklim/prakiraan-musim.bmkg.

[26] Sunergi. (2018) Paket PLTS Komersiil. [Online]. Available: http://www.sunergi.co.id/index.php/id/product/plts-bisnis/.

[27] (2018) Official Website of Bank Indonesia. [Online]. Available: http://www.bi.go.id.

[28] PT. PLN, Tarif Dasar Listrik Rumah Tangga (R1), PT. PLN, Jakarta. 2018.

[29] ESDM. (2018) Tarif Tenaga Listrik Indonesia Kompetitif di Kawasan ASEAN. [Online]. Available: https://www.esdm.go.id/id/mediacenter/arsip-berita/tarif-tenaga-listrik-indonesia-kompetitif-dikawasan-asean.

ISSN 1693-2951 I Kadek Sumariana : Penilaian Potensi Akomodasi Tipe... 